\title{
YIELD AND QUALITY OF TWO FLAX VARIETIES AS AFFECTED BY FOLIAR SPRAYING WITH POTASSIN RATES AND NITROGEN LEVELS UNDER SANDY SOIL CONDITION Hussein, M.M.M. and S.Z.A., Zedan \\ Fiber Crops Res. Dept., Field Crops Res. Instit. ARC Giza, Egypt
}

\begin{abstract}
Two field experiments were performed at the Experimental Farm, Esmailia Agric. Res. Station Agric. Res. Center, Esmailia Governorate, Egypt during the two growing seasons of 2003/2004 and 2004/2005 to study the influence of foliar spraying of potassin rates at (1 and 1.5 liters potassin/fed.) and the three nitrogen levels of 25, 50 and $75 \mathrm{~kg} \mathrm{~N} / \mathrm{fed}$. on yield, yield components and some technological characters of the two flax varieties Sakha 1 and Sakha 2. Moreover, simple correlation coefficient among straw and seed yields and their components as well as fiber yield and its quality were studied. Results obtained could be summarized as follows:

The flax variety Sakha 1 surpass Sakha 2 in total length, technical length, straw yield/plant as well as per feddan, fiber yield/plant as well as per feddan, fiber length and fiber fineness in both seasons in addition to the combined analysis over them. Fiber percentage had similar trend except with only the second season where Sakha 2 superior over Sakha 1 in this case without significance.

The flax variety Sakha 2 ranked first in no. of fruiting branches, no. of capsules/plant, no. of seeds/capsule, 1000 seed weight, seed yield/plant as well as per feddan, seed oil percentage and oil yield/fed.

Foliar spraying with potassin at the rate of 1.5 liter/fed. achieved maximum mean values of all straw and seed characters under study, except with fiber fineness trait, which recorded highest estimates by spraying with 1 liter, these results were true in both seasons and the combined data.

There was gradual increment in straw and seed yields in addition to their components with increasing nitrogen levels from 25 towards the highest dose at $75 \mathrm{~kg}$ $\mathrm{N} /$ fed., except with fiber fineness trait which more fine fiber obtained by applying 25 $\mathrm{kg} \mathrm{N} / \mathrm{fed}$. and more coarse fiber occurred with increasing nitrogen levels towards the highest level.

Straw yield/plant was highly significant and positive correlated with each of total length, technical length, fiber yield/plant, fiber yield/feddan and fiber length. Also, the $r$ values were highly significant and positive between seed yield and either no. of capsules/plant or 1000 seed weight.
\end{abstract}

\section{INTRODUCTION}

Flax (linum usitatissimum L.) is consider as one of oldest bast fiber crops. Flax play an important role in developing the national economy by its fiber exportation and local fabrication. Fresh linseed oil is used as human food and after boiling and treated chemically used as painting and varnish industries. Moreover, linseed cake is a valuable protein source to poultry and ruminants. Recently, the cultivated area by flax in Egypt tended to decrease in the valley lands due to great competition with other major winter crops. Therefore, the flax limited area was insufficient to provide with the progressive demands for Egyptian population. For this reason, the extension of flax cultivated area must be occur in newly reclaimed lands especially in sandy soils under modern sprinkler irrigation system. 
Yield of various flax genotypes were studied by many investigators in respect with yield., yield components and quality among of them Momtaz et al (1980 \& 1989), El-Farouk et al (2003) Zedan (2004), El-Shimy et al (2006), ElSweify et al (2006) and Atta et al (2007).

Potassin play vital role and stimulates biological process in the plant cell as enzymes activity, respiration, photosynthesis, chlorophyll, creation and water amounts in leaves and regulate stomata opining as well as a direct effect on the disease resistance. Many researchers reported about the important role of potassin as foliar spraying in increasing all characters studied of various flax genotypes among of them Ving Singir and Ramoar (1994), Khodyankova et al (1996), Zedan et al (1997), El-Gazzar and ElKady (2000), El-Shimy et al (2002), El-Azzouni et al (2003) and Hussein et al (2007).

Nitrogen is an essential element for flax growth to build up protoplasm and protein which induce cell division, merstemic activity and furtherly increased cell number and size with an overall increase in flax growth, consequently more fiber and seed production. Some investigators found that increasing $\mathrm{N}$ levels increased also yield and quality of flax such as Hella et al (1988), Jaggi et al (1995), Abd El-Samie et al (2002), El-Shimy et al (2002), Mostafa et al (2003), Salem et al (2006), Atta et al (2007) and Hussein et al (2007).

The sandy soil contains small amounts of nitrogen and organic matter in addition to few potassin element. Therefore, it could be compensate this case by adding nitrogen fertilizer levels and potassin as K- biofertilizer in foliar spray. In this respect, many studies should be carried out in this case to maximize the flax productivity on such new lands. Therefore, the main objective of this investigation was to study the influence of foliar spraying of potassin and different nitrogen levels on yield and quality as well as to study the simple correlation coefficients between different straw and seed characters for two flax cultivars under sandy soils conditions.

\section{MATERIALS AND METHODS}

Two field experiments were performed during 2003/2004 and 2004/2005 growing seasons in sandy soils at Esmailia Agric. Res. Station, Esmailia Governorate, Agric. Res. Center, Egypt to study the influence of potassin foliar spraying rates and nitrogen fertilizer levels on yield, yield components and some technological characters of fibers and seeds for two flax varieties. The soil of the experimental sites was sandy in texture. Mechanical and chemical analysis of the experimental field are presented in Table (1). In each season a spilt split plot design with four replications was used for each trait. The main plots contained the two flax varieties namely Sakha 1 and Sakha 2, the sub plots were to the two potassin fertilizer rates (1 and 1.5 liter potassin/fed.), the sub sub plots were assigned to three nitrogen fertilizer levels i.e. 25, 50 and $75 \mathrm{~kg} \mathrm{~N} / \mathrm{fed}$. The flax varieties i.e. Sakha 1 and Sakha 2 were selected from cross between Bombay X I. 1485 and between Hera X I. 2348, respectively. The experimental unit area was 6 $\mathrm{m}^{2}$ (1/700 fed.) with 10 rows $3 \mathrm{~m}$ long $20 \mathrm{~cm}$ apart. Seeds of flax cultivars 
were equally drilled in rows at the rate of $70 \mathrm{~kg}$ seeds/fed. The sowing dates were on 15 th and 17 th November in the first and second season, respectively. Other agricultural practices for growing flax were conducted as recommended. The experiments were preceded by peanut and sunflower crops in each of the two successive seasons, respectively. Nitrogen was added as ammonium nitrate $33.5 \% \mathrm{~N}$ for the three nitrogen levels under study in four equal doses for each one at 15, 30, 45 and 60 days from sowing, respectively. On the other hand, potassin nutrient $\left(30 \% \mathrm{~K}_{2} \mathrm{O}\right)$ was sprayed at the two rates i.e., 1 and 1.5 liter potassin/fed. twice after 40 and 60 days from sowing in spray volume at 200 liter water/fed. for each one in the first and second dates, respectively. Moreover, simple correlation coefficients were calculated between straw and seed yields and their components as well as fiber yield and its quality. Moreover, simple correlation coefficients were calculated between straw and seed yields and their components as well as fiber yield and its quality.

At maturity, ten guarded plants were pulled at random from each subsub plot to be used for recording yield components of straw and seed yields as well as fiber yield and its quality. However, straw, seeds and fiber yields/fed. were calculated from the sub-sub plot area basis. Data collected including the following characters:

\section{A- Straw yield and its components:}

Total length/plant $(\mathrm{cm})$, technical length/plant $(\mathrm{cm})$, straw yield/plant (g) and straw yield/fed. (ton).

\section{B- Seed yield and its components:}

Number of fruiting branches/plant, number of capsules/plant, number of seeds/capsule, 1000 seed weight $(\mathrm{g})$, seed yield/plant $(\mathrm{g})$, seed yield/fed. $(\mathrm{kg})$, seed oil percentage: determined according to the extraction method described by Horwitz et al (1965) using Sexhlet apparatus and petroleum ether. and oil yield/fed.

\section{C- Fiber yield and its quality:}

Fiber yield/plant (g), fiber yield/fed. (ton), fiber percentage, fiber length $(\mathrm{cm})$ and fiber fineness $(\mathrm{Nm})$, which estimated according to Radwan and Momtaz (1966) as follows: $\mathrm{Nm}=\mathrm{N} \times \mathrm{L} / \mathrm{G}$, where $\mathrm{Nm}$ : metrical number, $N$ : number of fibers $\{20$ fibers $\}$ L: fiber long $(20 \times 10 \times 10=2000)$ in $\mathrm{mm}$ and $\mathrm{G}$ :weight of fibers in $\mathrm{mg}$.

\section{Statistical analysis:}

All data collected were subjected to statistical analysis as described by Snedecor and Cochran (1982). Significance of differences among mean treatments judged with Least Significant Differences (L.S.D.) at $5 \%$ and $1 \%$ levels of significance. Moreover, combined analysis of variance over the two seasons were performed for each character according to Le Clerg et al (1966).

\section{Correlation studies:}

Simple correlation coefficients between different flax characters were calculated according to Svab (1973) as follows:

$r=S P x y /\left(S S x^{*} S S y\right)^{0.5}$ where : SPxy: is the phenotypic covariance between the two traits, SSx : is the phenotypic standard deviation of first trait and SSy: is the phenotypic standard deviations of the second one. 
Hussein, M.M.M. and S.Z.A., Zedan

Table (1): Mechanical and chemical analysis of the experimental soil (0-60 cm soil depth).

\begin{tabular}{|c|c|c|}
\hline \multirow{2}{*}{ variables } & \multicolumn{2}{|c|}{ Seasons } \\
\hline & $2003 / 2001$ & $2004 / 2005$ \\
\hline \multicolumn{3}{|c|}{ Mechanical analysis } \\
\hline Soil texture & Sandy & Sandy \\
\hline Coarse sand \% & 71.67 & 72.19 \\
\hline Fine sand \% & 20.16 & 21.06 \\
\hline Clay \% & 5.55 & 4.08 \\
\hline Silt \% & 2.62 & 2.67 \\
\hline \multicolumn{3}{|c|}{ Chemical analysis } \\
\hline $\mathrm{PH}$ value in 1:2. suspension & 8.14 & 7.92 \\
\hline Ec $\left(\mathrm{dsm}^{-1}\right)$ at $25 \mathrm{oC}$ & 0.48 & 0.35 \\
\hline Organic matter \% & 0.78 & 0.62 \\
\hline Available N (ppm) & 33.73 & 30.75 \\
\hline Available P (ppm) & 9.23 & 7.85 \\
\hline Available K (ppm) & 48.34 & 52.61 \\
\hline \multicolumn{3}{|l|}{ Cations (meg/L) } \\
\hline $\mathrm{Ca}^{++}$ & 1.35 & 1.48 \\
\hline $\mathrm{Mg}^{++}$ & 1.86 & 1.92 \\
\hline $\mathrm{N}^{++}$ & 0.68 & 0.62 \\
\hline \multicolumn{3}{|l|}{ Anions (meg/L) } \\
\hline $\mathrm{CO}_{3}^{-}$ & 0.07 & 0.06 \\
\hline $\mathrm{So}_{4}^{-}$ & 0.22 & 0.49 \\
\hline $\mathrm{CL}^{-}$ & 1.65 & 1.52 \\
\hline
\end{tabular}

\section{RESULTS AND DISCUSSION}

\section{A- Straw yield and its components:}

Results in Table (2) showed significant differences between the mean values for each of flax varieties, potassin rates and nitrogen levels in all four straw characters studied i.e., total length/plant, technical length/plant, straw yield/plant and straw yield/fed. in the two seasons and their combined data. The flax variety Sakha 1 achieved highest values of total length/plant, technical length/plant, straw yield/plant and straw yield/fed. in both seasons and combined data. The superiority ratios for Sakha 1 over Sakha 2 from the combined analysis were $7.02,11.44 .48 .98$ and $27.91 \%$ for the previous traits, respectively. The differences between these two flax varieties were mainly due to the genetically make up for each one. These results are in accordance with those obtained by Momtaz et al (1980 \& 1989), El-Farouk et al (2003), Zedan (2004), El-Shimy et al (2006), El-Sweify et al (2006) and Atta et al (2007). 
J. Agric. Sci. Mansoura Univ., 33 (6), June, 2008

Table(2) 
Regarding potassin fertilizer rate effect, data showed that foliar application with 1.5 liter potassin/fed. significantly increased all straw yield characters in the two successive seasons and combined over them. The excess percentage were $6.55,7.30,40.59$ and $27.82 \%$ between the highest rate of potassin and the lowest one for the previous traits, respectively as average from the combined analysis. These results could be attributed to the important role of potassin in stimulating biological process in plant as enzymes activity, respiration, photosynthesis, chlorophyll creation and water amount in leaves. Also stimulating effect especially on merestimatic tissue which produce more cells and more vegetative growth which in turn reflect on increasing straw yield and its components. These results are in harmony with those obtained by Khodyankova et al (1996), Ving Singir and Ramoar (1994), Zedan et al (1997), El-Gazzar and El-Kady (2000), El-Shimy et al (2002), ElAzzouni et al (2003) and Hussein et al (2007).

Owing to nitrogen fertilizer levels effect, data illustrated that there was gradual increase in each of straw characters i.e., total length/plant, technical length/plant, straw yield/plant and straw yield/fed. with increasing $\mathrm{N}$ levels from 25 up to $75 \mathrm{~kg} \mathrm{~N} / \mathrm{fed}$. in both seasons and the combined analysis. The superiority ratios between the averages obtained by maximum dose and the lowest one were $16.10,33.92,40.60$ and $50.12 \%$ for the previous traits, respectively as shown from the combined data. On the other hand, no significant differences among mean values of straw yield/plant as well as per feddan occurred as a result of added 50 and $75 \mathrm{~kg} \mathrm{~N} / \mathrm{fed}$. These results could be explained on the basis the favorable effect of nitrogen element for flax growth to build up protoplasm and proteins which induce cell division, merestimatic activity and furtherly flax growth and its yield. These results are in accordance with those obtained by Hella et al (1988), Jaggi et al (1995), El-Shimy et al (2002), Abd El-Samie et al (2002), Mostafa et al (2003), Salem et al (2006), Atta et al (2007) and Hussein et al (2007).

\section{B- Fiber yield and its quality:}

As shown from Table (3), data revealed that flax varieties significantly differed in fiber characters i. e., fiber yield/plant, fiber yield/fed, fiber length and fiber fineness with an exception for fiber percentage trait which did not reached the level of significance. Moreover, the mean values for each of potassin rates and nitrogen levels differed significantly in both seasons and combined data concerning all five fiber traits.

With respect to varietal differences, Sakha 1 ranked first and recorded highest values of fiber yield/plant, fiber yield/fed, fiber percentage, fiber length and fiber fineness from the combined analysis and outyielded Sakha 2 by $57.65,34.67,4.58,12.36$ and $5.41 \%$ for the previous traits, respectively. Similar results were obtained by Momtaz et al (1980 \& 1989), El-Farouk et al (2003), Zedan (2004), El-Shimy et al (2006), El-Sweify et al (2006) and Atta et al (2007). 
J. Agric. Sci. Mansoura Univ., 33 (6), June, 2008

Table(3)

3943 
The foliar spraying with potassin rate at 1.5 liter/fed. resulted the highest values of fiber yield/plant, fiber yield/fed, fiber percentage and fiber length when compared with the lowest rate (1 liter potassin/fed.) The superiority ratios from the combined analysis between the highest rate of potassin and the lowest one were 56.25, 39.78, 9.97 and $8.51 \%$ for the previous traits, respectively. Meanwhile, remarkable reduction had been observed in fiber fineness trait due to increase potassin rate from 1 to 1.5 liter/fed. The decrement was $5.74 \%$ for this trait. Increasing fiber yield/fed. with increasing potassin rates were reported by Hella et al (1988), Ving Singir and Ramoar (1994), Khodyankova et al (1996), Zedan et al (1997), El-Gazzar and El-Kady (2000), El-Shimy et al (2002) and El Azzouni et al (2003).

There was a significant increase in each of fiber yield/plant, fiber yield/fed, fiber percentage and fiber length with increasing $\mathrm{N}$ levels from 25 up to $75 \mathrm{~kg} \mathrm{~N} / \mathrm{fed}$. with an exception with fiber fineness trait which decreased by $11.88 \%$ between the highest and the lowest nitrogen levels. The increment between the highest and the lowest averages were 68.83, 81.75, 20.98 and $21.21 \%$ for the previous four traits, respectively as calculated from the combined data. On the other hand, no significant differences among mean values of fiber yield/fed. and fiber percentage as result of added 50 and $75 \mathrm{~kg}$ $\mathrm{N} / \mathrm{fed}$. These findings are in accordance with those obtained by Hella et al (1988), Jaggi et al (1995), Zedan et al (1997) Abd El-Samie et al (2002), ElShimy et al (2002), Mostafa et al (2003),Salem et al (2006), Atta et al (2007) and Hussein et al (2007).

The interaction between potassin $(P)$ and nitrogen $(N)$ had significant effect on total length character with the maximum mean value of $79.93 \mathrm{~cm}$ which achieved by foliar spraying with potassin at the rate of 1.5 liter/fed. combined with nitrogen level of $75 \mathrm{~kg} \mathrm{~N} / \mathrm{fed}$.

The interaction between flax varieties $(\mathrm{V})$ and potassin $(\mathrm{P})$ had significant effect on fiber yield/plant and fiber percentage which obtained by Sakha $10.509 \mathrm{~g}$ and $14.57 \%$, respectively and combined with spraying potassin at the rat of $1.5 \mathrm{liter} / \mathrm{fed}$.

$\mathrm{V} \times \mathrm{N}$ interaction had significant effect on fiber fineness character, the highest estimate $186.689 \mathrm{Nm}$ obtained by Sakha 1 combined with the nitrogen level of $75 \mathrm{~kg} \mathrm{~N} / \mathrm{fed}$.

Table (4): Mean values of total length/plant as affected by the interaction between potassin rates and nitrogen fertilizer levels (combined analysis of 2003/2004 and 2004/2005 seasons).

\begin{tabular}{|c|c|c|c|}
\hline \multirow{2}{*}{$\begin{array}{c}\text { Potassin rates } \\
\text { (liter/fed.) }\end{array}$} & \multicolumn{3}{|c|}{ Nitrogen fertilizer levels (kg N/fed.) } \\
\cline { 2 - 4 } & $\mathbf{2 5}$ & $\mathbf{5 0}$ & $\mathbf{7 5}$ \\
\hline 1 & 63.94 & $\mathbf{7 4 . 8 0}$ & 76.36 \\
\hline 1.5 & 70.67 & 78.61 & 79.93 \\
\hline L.S.D. 5\% & 4.99 & 3.40 & 2.81 \\
\hline
\end{tabular}


Table (5): mean values of fiber yield/plant and fiber percentage as affected by the interaction between flax varieties and potassin rates (combined analysis of 2003/2004 and 2004/2005 seasons).

\begin{tabular}{|c|c|c|c|c|}
\hline \multirow{2}{*}{ Varieties } & \multicolumn{3}{|c|}{ Fiber yield/plant (g) } & \multicolumn{2}{c|}{ Fiber percentage } \\
\cline { 2 - 5 } & \multicolumn{3}{|c|}{ Potassin rates (liter/fed.) } \\
\cline { 2 - 5 } & $\mathbf{1}$ & $\mathbf{1 . 5}$ & $\mathbf{1}$ & $\mathbf{1 . 5}$ \\
\hline Sakha 1 & 0.293 & 0.509 & 12.34 & 14.57 \\
\hline Sakha 2 & 0.218 & 0.290 & 12.73 & 13.00 \\
\hline L.S.D. 5\% & 0.061 & 0.119 & 0.18 & 1.10 \\
\hline
\end{tabular}

Table (6): Mean values of fiber fineness as affected by the interaction between flax varieties and nitrogen fertilizer levels (combined analysis of 2003/2004 and 2004/2005 seasons).

\begin{tabular}{|c|c|c|c|}
\hline \multirow{2}{*}{ Varieties } & \multicolumn{3}{|c|}{ Nitrogen fertilizer levels (kg N/fed.) } \\
\cline { 2 - 4 } & $\mathbf{2 5}$ & $\mathbf{5 0}$ & $\mathbf{7 5}$ \\
\hline Sakha 1 & 214.26 & 201.80 & 186.68 \\
\hline Sakha 2 & 201.68 & 190.28 & 179.84 \\
\hline L.S.D. 5\% & 9.80 & 8.50 & 5.90 \\
\hline
\end{tabular}

\section{C- Seed yield and its components:}

Mean values of eight characters related to seed yield for two flax varieties as affected by potassin rates and nitrogen levels in 2003/2004 and $2004 / 2005$ as well as their combined analysis are presented in Tables 7 and 8 .

Statistical analysis of variance showed significant differences between each of flax varieties, potassin rates and nitrogen levels for the eight characters under study i.e., number of fruiting branches/plant, number of capsules/plant, number of seeds/capsule, 1000 seed weight, seed yield/plant, seed yield/fed., seed oil percentage and oil yield/fed. It could be noticed that Sakha 2 variety produced the highest values of seed yield and its components in addition to outyielded Sakha 1 variety by $54.52,61.87,15.85$, $10.04,35.40,25.82,2.97$ and $29.45 \%$ for the previous traits, respectively from the combined analysis. The superiority of Sakha 2 in seed yield/fed. may be attributed to the increase in number of fruiting branches/plant, number of capsules/plant, number of seeds/capsule, 1000 seed weight and seed yield/plant. Similar results were reported by Momtaz et al (1980 \& 1989), ElFarouk et al (2003) El-Azzouni et al (2003), Mostafa et al (2003), El-Shimy et al (2006), El-Sweify et al (2006), Atta et al (2007), Hussein (2007) and Hussein et al (2007).

Regarding potassin rates effect, data in Tables 7 and 8 indicated that increasing potassin rate from 1 to $1.5 \mathrm{liter} / \mathrm{fed}$. increased significantly all eight seed characters The superiority ratios from the combined analysis between the highest potassin rate and the lowest one were 22.41, 22.75, 15.15, 9.14, $19.08,10.32,4.63$ and $15.24 \%$ for the previous traits, respectively. Many investigators detected the important role of potassin in flax among of them Hella et al (1989), Khodyankova et al (1996), Ving Singir and Ramoar (1994), Zedan et al (1997), El-Gazzar and El-Kady(2000), El-Shimy et al (2002), ElAzzouni et al (2003) and Hussein et al (2007). 
Hussein, M.M.M. and S.Z.A., Zedan

Table(7) 
J. Agric. Sci. Mansoura Univ., 33 (6), June, 2008

Table(8) 
With respect to nitrogen levels effect, data reveled significant increase in seed characters with increasing $\mathrm{N}$ levels from 25 up to $75 \mathrm{~kg}$ $\mathrm{N} / \mathrm{fed}$. The increment from the combined data were 50.49, 52.79, 24.57, $14.30,59.05,44.04,6.36$ and $53.10 \%$ for the previous traits, respectively. On the other hand, no significant differences among mean values of 1000 seed weight, seed yield/fed., seed oil percentage and oil yield/fed. as result of added 50 and $75 \mathrm{~kg} \mathrm{~N} / \mathrm{fed}$. These results are in harmony with those obtained by Hella et al (1988), Jaggi et al (1995), Zedan et al (1997), Abd El-Samie et al (2002), El-Shimy et al (2002), Mostafa et al (2003),Salem et al (2006), Atta et al (2007) and Hussein et al (2007).

The combined analysis for data in presented Table (9) showed that number of seeds/capsule trait affected significantly by the interaction between flax varieties and nitrogen levels. The highest number of seeds/capsule was obtained by Sakha 2 when fertilized with $75 \mathrm{~kg} \mathrm{~N} / \mathrm{ed}$.

From the combined analysis for both seasons, data presented in Table (10) revealed that the interaction between flax varieties and potassin rates had significant effect on seed yield/plant. The maximum values of this character was resulted from Sakha 2 when sprayed with 1.5 liter potassin/fed.

Table (9):Mean values of number of seeds/capsule as affected by the interaction between flax varieties and nitrogen fertilizer levels (combined analysis of 2003/2004 and 2004/2005 seasons).

\begin{tabular}{|c|c|c|c|}
\hline \multirow{2}{*}{ Varieties } & \multicolumn{3}{|c|}{ Nitrogen fertilizer levels (kg N/fed.) } \\
\cline { 2 - 4 } & $\mathbf{2 5}$ & $\mathbf{5 0}$ & $\mathbf{7 5}$ \\
\hline Sakha 1 & 5.39 & 6.23 & 6.74 \\
\hline Sakha 2 & 6.17 & 7.44 & 7.67 \\
\hline L.S.D. 5\% & 0.55 & 0.98 & 0.85 \\
\hline
\end{tabular}

Table (10): mean values of seed yield/plant as affected by the interaction between flax varieties and potassin rates (combined analysis of 2003/2004 and 2004/2005 seasons).

\begin{tabular}{|c|c|c|}
\hline \multirow{2}{*}{ Varieties } & \multicolumn{2}{|c|}{ Potassin rates (liter/fed.) } \\
\cline { 2 - 3 } & $\mathbf{1}$ & $\mathbf{1 . 5}$ \\
\hline Sakha 1 & 0.420 & 0.545 \\
\hline Sakha 2 & 0.618 & 0.690 \\
\hline L.S.D. 5\% & 0.156 & 0.135 \\
\hline
\end{tabular}

\section{Correlation studies:}

Data presented in Table (11) showed positive and highly significant correlation coefficients between straw yield/fed. and each of straw yield/plant, total length/plant, technical length/plant, fiber yield/fed., fiber yield/plant and fiber length. Similar results were obtained by Badwal et al (1971), Momtaz et al (1977), El-Shaer et al (1983), El-Azzouni et al (2003), El-Shimy et al (2006), El-Sweify et al (2006) and Hussein (2007). 
J. Agric. Sci. Mansoura Univ., 33 (6), June, 2008

Table(11) 
Positive and highly significant association was found between straw yield/plant and each of total and technical length/plant, fiber yield/fed., fiber yield/plant and fiber length. Moreover, positive and insignificant correlation was found between straw yield/fed. and each of seed yield/fed., seed yield/plant, number of capsules/plant and 1000 seed weight. These results are in agreement with those reported by Al-Kaddoussi and Moawad (2001), Zedan (2004), El-Shimy et al (2006) and El-Sweify et al (2006).

Seed yield/fed. was positively and highly significant correlated with each of seed yield/plant, number of capsules/plant and 1000 seed weight. Also positive and highly significant correlation was found between seed yield/plant and each of number of capsules/plant and 1000 seed weight. These results are in accordance with those obtained by Momtaz et al (1977), El-Shaer and Momtaz (1983), Zahana (1994), and Hussein et al (2007).

\section{Conclusion:}

From the present work. It can be concluded that for maximum production from straw and seed achieved by spraying flax varieties namely Sakha 1 and Sakha 2 with potassin at the rate of 1.5 liter/fed. and flax plants must be fertilized with $75 \mathrm{~kg} \mathrm{~N} / \mathrm{fed}$. under the condition of this study. Moreover, plant breeder must take care for plant length trait as indication to more straw, in addition to no. of capsules/plant as explanation to more seed yield.

\section{REFERENCES}

Abdel-Samie, F.S.; M.A. Abdel-Dayem and S.Z.A. Zedan (2002). Response of some flax genotypes to bacterial inoculation and nitrogen levels under newly reclaimed lands. Annals of Agric. Sci., Moshtohor 40 (2): 713-722.

Al-Kaddousi, A.R. and E.A. Moawed (2001). Yield analysis of seed and straw and yield components under three row spacing for some genotypes of flax (Linum usitatissimum L.) Egypt J. Appl. Sci., 16 (21): 426-441.

Atta, Y.I.M.; M.M.M., Hussein and A.A. Nassar (2007). Some factors affecting linseed (Linum usitatissimum L.) yield, quality and water use efficiency. Zagazig J. Agric. Res. 34 (4): 617-642.

Badwal, S.S.; K., Singh Gill and Harbans Singh (1971). Correlation and regression studiws in linseed (Linum usitatissimum L.). Ind. J. Agric. Sci., 41(5): 475-478.

El-Azzouni, A.M.A; E.A Moawed and S.M. Salama (2003). Effect of seeding rates and potassin fertilizer on some genotypes of flax (Linum usitatissimum L.) J.Agric. Sci. Mansoura Univ. 28 (8): 5887-5902.

El-Farouk, M.; E.A.F. El-Kady; A.M. Hella; M.E.A. Kineber; N.K.M. Mourad; S.H. Mostafa; S.Z. Zedan; Eman A. El-Kady and T.A. Abou Zaied (2003). Releasing of two New flax varieties "Sakha 1" and "Sakha 2". Fayoum J. Agric. Res \& Dev. 17 (2): 1-8.

El-Gazzar, A.A.M. and E.A.F. El-Kady (2000). Effect of nitrogen levels and foliar application with Nofatrin, Gtrin, Potassin and Ascopin on growth, yield and quality of flax. J. Agric. Res. 45 (3): 67-80. 
El-Shaer; M.H. A. Momtaz, M.M. Samia and A.M. Hella (1983). The association among straw, seed and fiber yields and other characters in flax growth at Giza A.R.E. Annals of Agric Sci. Moshtohor 20 : 195-209.

El-Shimy, G.H.; M.M.M., Hussein and Amany M.M. El-Refai (2006).Effect of Nofatrin ( $\mathrm{N}$ bio-fertilizer) application times on yield and yield components of some flax varieties. J. Agric. Sci., Mansoura Univ. 31 (6): 3295-3307.

El-Shimy, G.H.; S.H., Moatafa and M.A., Abd El-Dayem (2002): Effect of NPK fertilizer levels on yield and its components of some flax genotypes. Annals of Agric. Sc. Moshtohor. 40 (1):67-79.

El-Sweify,H.H. Amna; M.A., Abd El-Dayem and M.M.M., Hussein (2006). Response of some flax genotypes to pulling date under newly reclaimed sandy soil and sprinkler irrigation conditions. Egypt J. Agric. Res. 84 (4): 1103-1115.

Hella, A.M.A.; N.K.M. Mourad and S.M. Gaafer (1988). Effect of NPK fertilizer application on yield and its components in flax (Linum usitatissimum L.) Egypt J. Agron., 66 (3): 1-13.

Horwitz, W.; A,H. Robertson; E.A. Epps; F.W. Ackenush and H. Reynolds (1965). Official methods of analysis of association of official agricultural chemists, Washington, O.A.C.

Hussein, M.M.M. (2007). Response of some flax genotypes to bio and nitrogen fertilization. Zagazig J. Agric. Res. 34 (5): 815-844.

Hussein, M.M.M.; M.A., Abd El-Dayem and Amany M.M. El-Refai (2007). Effect of plant density and potassium fertilizer on yield and its quality of some flax genotypes under sandy soil conditions. J. agric. Sci., Mansoura Univ. 32 (1): 99-115.

Jaggi, R.C., R.S.; Kanwal. and S.P. Dixit (1995). Effect of fertilizer N and S interaction on composition and uptake of nutrients by linseed. J. Ind. Soc. Soil Sci., 43 (4): 611-615.

Khodyankova, S.F.; S. Kukresh and Z.D. Amflmova (1996). Energy saving technique flax applying fertilizer for fiber flax. Agrokhimya 11: 87-94. CF. Field Crop Abst. 50 (12): 9366>

Le Clerg, E.; W.E., Leonard and A.G., Clark (1966). Field plot technique. Burgross Publishing Co. Minneapoli. Minnesota, USA.

Momtaz, A..; M. El-Farouk; G. El-Shimy, A. Ibrahim; S. Soliman; A. Mohamed and A. El- Atter (1980). New flax varieties Giza 5 and Giza 6. Agric Res. Rev. (8): 24-40.

Momtaz, A..; M. El-Farouk; N.K. Mourad; T. Nasr El-in; E.A.F. El-Kady and A.M.A. Hella (1989). New flax varieties Giza 7 and Giza 8. Agric Res. Rev. 68 (7): 1461-1475.

Momtaz, A..; A.K.A. Salim and G.H. El-Shimy (1977). Correlation studies on some flax crosses and their reciprocal in Egypt. Association studies between flax seed yield and some other characters. Agric. Res. Rev. 55: 45-55.

Mostafa, S.H.; M.E.A. Kineber and A.A.E. Mohamed (2003): Effect of inoculation with phosphorine and nitrobin on flax yield and some anatomical characters under different nitrogen levels. J. Agric. Sci. Mansoura Univ., 28 (6): 4307-4323. 
Radwan, S.R.A and A., Momtaz (1966). The technological properties for flax fiber and the methods of estimating them. El-Felaha J. 46 (5): 466-476.

Salem, M.S.A.; S.Z.A. Zedan and M.M. Esmail (2006). Effect of some biological and mineral fertilizers on some growth and yield characters of two flax cultivars. Bull. Fac. Agric. Cairo Univ. 57 (2): 261-276.

Snedecor, G.W. and W.G., Cochran (1982). Statistical Method. 7 th. Edition, lawa State Univ., Press. Ames., lawa USA.

Svab, J. (1973) Biometric modszerck a Kutatsban. Mezoazdasgi Kiado Budapest.

Ving Singir and S.S. Romoar (1994). Effect of applied potassium and sulphuo on yield, oil cotent and their uptake by linseed. J. of potassium Res. 10 (4): 407-410.

Zahana Afaf, E.A. (1999). Correlation and regression studies in flax. Ph.D. thesis Fac. Agric., Moshtohor Zagazig Univ.

Zedan, S.Z. (2004). Response of some flax varieties to planting methods and plant densities. Egypt J. Appl.Sci. 19 (9): 108-121.

Zedan, S.Z.; M.E.A. Kineber and S.H.A. Mostafa (1997). Response of flax to potassium and nitrogen fertilization under sandy soil conditions. Egypt J. Agric Res. 27 (2): 729-743.

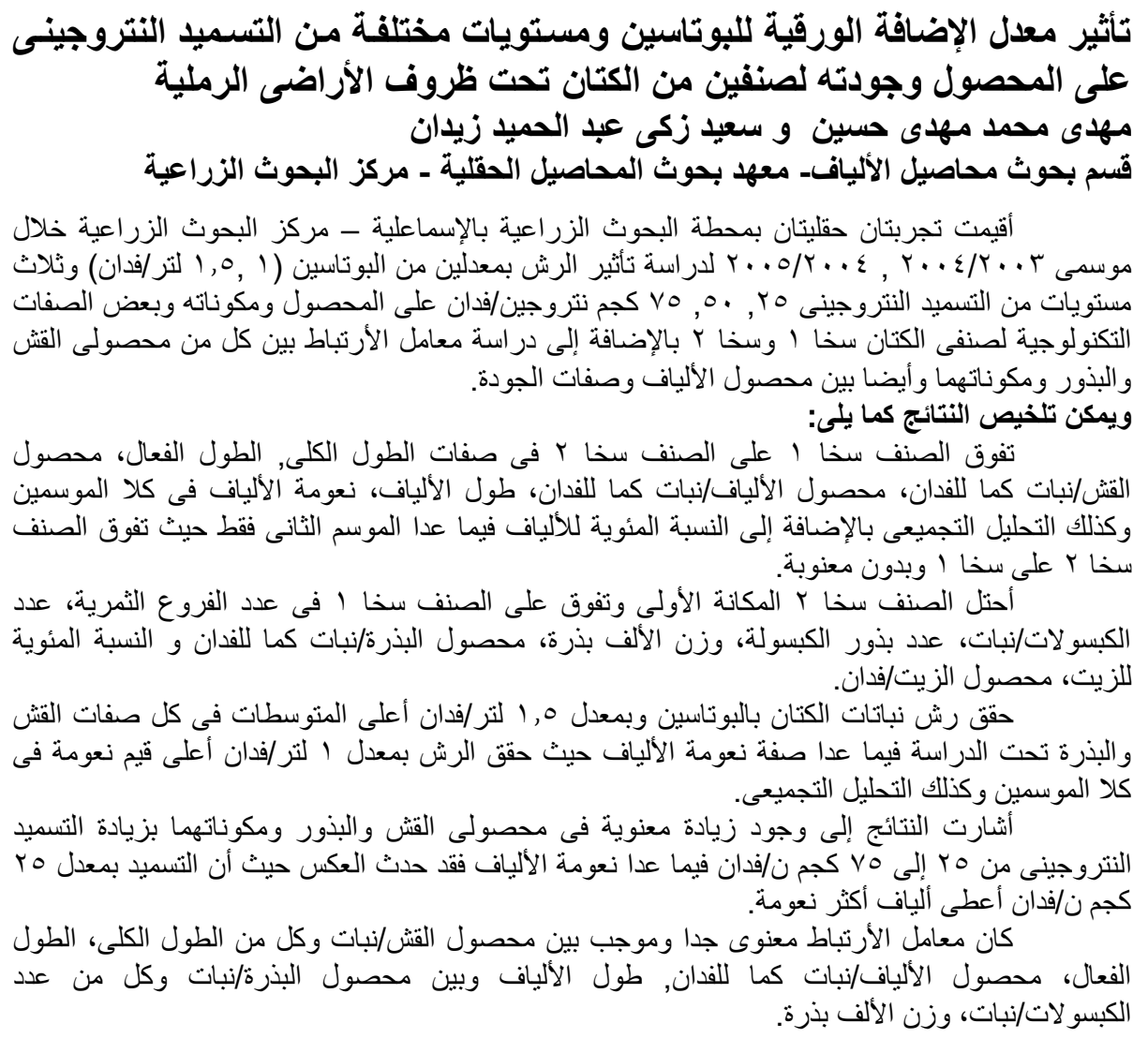


Table (2): Mean values of straw yield and its related characters for two flax varieties as affected by potassin rates, nitrogen fertilizer levels and their interaction in 2003/2004 and 2004/2005 seasons in addition to the combined analysis.

\begin{tabular}{|c|c|c|c|c|c|c|c|c|c|c|c|c|}
\hline Characters & \multicolumn{3}{|c|}{$\begin{array}{l}\text { Total length } \\
\text { /plant }(\mathrm{cm})\end{array}$} & \multicolumn{3}{|c|}{$\begin{array}{c}\begin{array}{c}\text { Technical length/plant } \\
(\mathbf{c m})\end{array} \\
\end{array}$} & \multicolumn{3}{|c|}{$\begin{array}{c}\text { Straw } \\
\text { yield/plant (g) }\end{array}$} & \multicolumn{3}{|c|}{$\begin{array}{c}\text { Straw } \\
\text { yield/fed. (ton) }\end{array}$} \\
\hline Treatments & $1^{\text {st }}$ & $2^{\text {nd }}$ & Comb. & $1^{\text {st }}$ & $2^{\text {nd }}$ & Comb. & $1^{\text {st }}$ & $2^{\text {nd }}$ & Comb. & $1^{\text {st }}$ & $2^{\text {nd }}$ & Comb \\
\hline \multicolumn{13}{|c|}{ Varieties: } \\
\hline$V_{1}:$ Sakha 1 & 81.56 & 71.56 & 76.56 & 70.25 & 68.24 & 69.25 & 3.123 & 2.693 & 2.908 & 2.666 & 2.623 & 3.144 \\
\hline$V_{2}:$ Sakha 2 & 74.81 & 68.28 & 71.54 & 64.52 & 59.77 & 62.14 & 2.014 & 1.890 & 1.952 & 2.727 & 2.188 & 2.458 \\
\hline F.test & * & * & * & * & ${ }^{*}$ & * & $\star *$ & ${ }^{*}$ & ** & * & ** & $\star *$ \\
\hline \multicolumn{13}{|c|}{ Potassin rates } \\
\hline P1: 1 liter/fed. & 74.99 & 68.42 & 71.70 & 64.62 & 62.14 & 63.38 & 2.149 & 1.891 & 2.020 & 2.860 & 2.058 & 2.459 \\
\hline P2: 1.5 liter/fed. & 81.39 & 71.42 & 76.40 & 70.14 & 65.87 & 68.01 & 2.988 & 2.692 & 2.840 & 3.533 & 2.752 & 3.143 \\
\hline L.S.D. 5\% & 4.09 & 2.07 & 3.50 & 4.82 & 2.71 & 4.33 & 0.600 & 0.701 & 0.630 & 0.505 & 0.55 & 0.510 \\
\hline L.S.D. 1\% & 6.03 & N.S. & 4.61 & 5.5 & N.S. & 4.60 & 0.763 & 0.800 & 0.790 & 0.630 & 0.620 & 0.625 \\
\hline \multicolumn{13}{|c|}{ Nitrogen fertilizer levels } \\
\hline N1: 25 kg N/fed. & 69.92 & 64.69 & 67.31 & 56.80 & 55.99 & 56.39 & 2.144 & 1.748 & 1.946 & 2.353 & 1.929 & 2.141 \\
\hline N2: $50 \mathrm{~kg} \mathrm{~N} / \mathrm{fed}$. & 81.45 & 71.97 & 76.71 & 71.52 & 66.82 & 69.17 & 2.704 & 2.513 & 2.608 & 3.508 & 2.587 & 3.048 \\
\hline N3: $75 \mathrm{~kg} \mathrm{~N} / \mathrm{fed}$ & 83.19 & 73.10 & 78.15 & 73.84 & 69.20 & 71.52 & 2.857 & 2.614 & 2.736 & 3.729 & 2.700 & 3.214 \\
\hline L.S.D. 5\% & 6.31 & 5.25 & 7.32 & 9.83 & 8.31 & 7.12 & 0.392 & 0.511 & 0.499 & 0.819 & 0.311 & 0.532 \\
\hline L.S.D. 1\% & 9.22 & 6.05 & 8.90 & 11.5 & 10.3 & 9.81 & 0.512 & 0.696 & 0.610 & 1.06 & 0.599 & 0.811 \\
\hline \multicolumn{13}{|c|}{ Interactions } \\
\hline $\mathbf{V} \times P$ & N.S. & N.S. & N.S. & N.S. & N.S. & N.S. & N.S. & N.S. & N.S. & N.S. & * & N.S. \\
\hline $\mathrm{V} \times \mathrm{N}$ & N.S. & N.S. & N.S. & N.S. & N.S. & N.S. & N.S. & N.S. & N.S. & $*$ & N.S. & N.S. \\
\hline $\mathbf{N} \times \mathbf{P}$ & N.S. & * & * & * & N.S. & N.S. & N.S. & N.S. & N.S. & N.S. & * & N.S. \\
\hline $\mathbf{V} \times \mathbf{P} \times \mathbf{N}$ & N.S. & N.S. & N.S. & N.S. & N.S. & N.S. & N.S. & N.S. & N.S. & N.S. & N.S. & N.S. \\
\hline
\end{tabular}


Table (3): Mean values of fiber yield and its quality for two flax varieties as affected by potassin rates, nitrogen fertilizer levels and their interaction in 2003/2004 and 2004/2005 seasons in addition to the combined analysis.

\begin{tabular}{|c|c|c|c|c|c|c|c|c|c|c|c|c|c|c|c|}
\hline Characters & \multicolumn{3}{|c|}{$\begin{array}{l}\text { Fiber yield } \\
\text { /plant (g) }\end{array}$} & \multicolumn{3}{|c|}{$\begin{array}{c}\text { Fiber yield/fed. } \\
\text { (ton) }\end{array}$} & \multicolumn{3}{|c|}{$\begin{array}{c}\text { Fiber } \\
\text { percentage }\end{array}$} & \multicolumn{3}{|c|}{$\begin{array}{c}\text { Fiber } \\
\text { length }(\mathbf{c m}) \\
\end{array}$} & \multicolumn{3}{|c|}{$\begin{array}{c}\text { Fiber } \\
\text { fineness }(\mathrm{Nm})\end{array}$} \\
\hline $\begin{array}{|ll|}\text { Treatments } & \text { Season } \\
\end{array}$ & $1^{\text {st }}$ & $2^{\text {nd }}$ & Comb. & 1 st & $2^{\text {nd }}$ & Comb. & $1^{\text {st }}$ & $2^{\text {nd }}$ & Comb. & 1 st & $2^{\text {nd }}$ & Comb. & 1 st & $2^{\text {nd }}$ & Comb. \\
\hline \multicolumn{16}{|c|}{ Varieties: } \\
\hline $\mathrm{V}_{1}$ : Sakha 1 & 0.445 & 0.357 & 0.402 & 0.524 & 0.346 & 0.435 & 13.96 & 12.96 & 13.46 & 72.04 & 66.36 & 69.20 & 205.38 & 196.44 & 200.91 \\
\hline$V_{2}:$ Sakha 2 & 0.249 & 0.260 & 0.255 & 0.345 & 0.301 & 0.323 & 12.17 & 13.56 & 12.87 & 64.75 & 58.44 & 61.59 & \begin{tabular}{|l|}
194.04 \\
\end{tabular} & 187.17 & 190.60 \\
\hline F.test & * & N.S. & 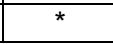 & * & 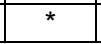 & ** & N.S. & N.S. & N.S. & * & * & ** & ** & $\%$ & *夫 \\
\hline \multicolumn{16}{|c|}{ Potassin rates } \\
\hline P1: 1 liter/fed. & 0.275 & 0.237 & 0.256 & 0.374 & 0.258 & 0.316 & 12.53 & 12.54 & 12.54 & 65.25 & 60.21 & 62.73 & \begin{tabular}{|l|}
205.82 \\
\end{tabular} & 198.02 & 201.92 \\
\hline P2: 1.5 liter/fed. & 0.420 & 0.380 & 0.400 & 0.496 & 0.388 & 0.442 & 13.60 & 13.98 & 13.79 & 71.54 & 64.59 & \begin{tabular}{|l|}
68.07 \\
\end{tabular} & 193.60 & 185.58 & 190.34 \\
\hline L.S.D. 5\% & 0.125 & 0.129 & 0.136 & 0.115 & 1.9 & 0.110 & 1.33 & 1.23 & 1.09 & 4.99 & 3.25 & 4.72 & 10.20 & 11.50 & 9.25 \\
\hline L.S.D. 1 & 0.143 & 0.138 & 0.141 & 0.120 & 0.121 & 0.118 & N.S. & 1.40 & 1.21 & 5.82 & N.S. & 5.22 & 11.82 & 12.75 & 10.31 \\
\hline \multicolumn{16}{|c|}{ Nitrogen fertilizer levels } \\
\hline N1: 25 kg N/fed. & 0.250 & 0.212 & 0.231 & 0.269 & 0.235 & 0.252 & 11.20 & 12.17 & 11.68 & 60.32 & 55.77 & 58.04 & 211.42 & 205.52 & 207.97 \\
\hline N2: 50 kg N/fed. & 0.384 & 0.342 & 0.363 & 0.503 & 0.350 & 0.426 & 13.89 & 13.45 & 13.67 & 71.35 & 64.23 & 67.79 & 201.33 & 204.52 & 196.04 \\
\hline N3: $75 \mathrm{~kg} \mathrm{~N} / \mathrm{fed}$ & 0.408 & 0.373 & 0.390 & 0.533 & 0.384 & 0.458 & 14.11 & 14.16 & 14.13 & 73.51 & 67.19 & 70.35 & 186.38 & 180.14 & 183.26 \\
\hline L.S.D. 5\% & 0.025 & 0.087 & 0.105 & 0.162 & 0.110 & 0.161 & 2.10 & 1.00 & 1.61 & 9.11 & 7.80 & 6.35 & 8.25 & 9.33 & 8.11 \\
\hline L.S.D. 1 & 0.122 & 0.115 & 0.125 & 0.215 & 0.114 & 0.170 & 2.51 & 1.21 & 1.96 & 10.82 & 8.35 & 9.40 & 9.71 & 21.5 & 9.80 \\
\hline \multicolumn{16}{|c|}{ Interactions } \\
\hline $\mathbf{V} \times \mathbf{P}$ & $\star \star \star$ & * & ** & N.S. & N.S. & N.S. & * & ** & ** & N.S. & N.S. & N.S. & N.S. & N.S. & N.S. \\
\hline $\mathbf{V} \times \mathbf{N}$ & N.S. & N.S. & N.S. & N.S. & N.S. & N.S. & N.S. & N.S. & N.S. & N.S. & N.S. & N.S. & N.S. & * & * \\
\hline $\mathbf{N} \times \mathbf{P}$ & N.S. & * & N.S. & N.S. & * & N.S. & N.S. & N.S. & N.S. & N.S. & N.S. & N.S. & N.S. & * & N.S. \\
\hline $\mathbf{V} \times \mathbf{P} \times \mathbf{N}$ & N.S. & * & N.S. & N.S. & N.S. & N.S. & N.S. & N.S. & N.S. & N.S. & N.S. & N.S. & N.S. & N.S. & N.S. \\
\hline
\end{tabular}


Table (7): Mean values of four characters related to seed yield for two flax varieties as affected by potassin rates, nitrogen fertilizer levels and their interaction in 2003/2004 and 2004/2005 seasons in addition to the combined analysis.

\begin{tabular}{|c|c|c|c|c|c|c|c|c|c|c|c|c|}
\hline Characters & \multicolumn{3}{|c|}{$\begin{array}{l}\text { No. of fruiting } \\
\text { branches/plant }\end{array}$} & \multicolumn{3}{|c|}{$\begin{array}{c}\text { No. of capsules } \\
\text { /plant }\end{array}$} & \multicolumn{3}{|c|}{$\begin{array}{l}\text { No. of seeds } \\
\text { /capsule }\end{array}$} & \multicolumn{3}{|c|}{$\begin{array}{l}1000 \text { seed } \\
\text { weight }(\mathrm{g})\end{array}$} \\
\hline \begin{tabular}{|ll} 
Treatments & Season \\
\end{tabular} & $1^{\text {st }}$ & $2^{\text {nd }}$ & Comb. & 1 st & $2^{\text {nd }}$ & Comb. & $1^{\text {st }}$ & $2^{\text {nd }}$ & Comb. & $1^{\text {st }}$ & $2^{\text {nd }}$ & Comb. \\
\hline \multicolumn{13}{|c|}{ Varieties } \\
\hline$V_{1}$ : Sakha 1 & 7.71 & 7.11 & 7.41 & 6.69 & 5.94 & 6.32 & 6.74 & 5.50 & 6.12 & 8.30 & 8.05 & 8.17 \\
\hline$V_{2:}$ Sakha 2 & 12.47 & 10.43 & 11.45 & 11.13 & 9.34 & 10.23 & 7.69 & 6.50 & 7.09 & 9.18 & 8.81 & 8.99 \\
\hline F.test & ** & $\star *$ & ** & $\star *$ & $\star *$ & ** & $*$ & $*$ & $\star *$ & $* *$ & $* *$ & $\star *$ \\
\hline \multicolumn{13}{|c|}{ Potassin rates } \\
\hline P1: 1 liter/fed. & 8.92 & 8.04 & 8.48 & 7.83 & 6.03 & 6.93 & 6.62 & 5.67 & 6.14 & 8.33 & 8.09 & 8.21 \\
\hline P2: 1.5 liter/fed. & 11.26 & 9.50 & 10.38 & 9.99 & 9.26 & 9.62 & 7.81 & 6.33 & 7.07 & 9.15 & 8.77 & 8.96 \\
\hline L.S.D. 5\% & 1.89 & 1.30 & 1.55 & 1.86 & 2.10 & 2.18 & 1.15 & 0.45 & 0.81 & 0.75 & 0.55 & 0.62 \\
\hline L.S.D. 1\% & 2.04 & N.S. & 1.88 & 2.04 & N.S. & 2.50 & 1.18 & N.S. & 0.900 & 0.80 & 0.61 & 0.72 \\
\hline \multicolumn{13}{|c|}{ Nitrogen fertilizer levels } \\
\hline N1: $25 \mathrm{~kg} \mathrm{~N} / \mathrm{fed}$ & 7.80 & 6.61 & 7.21 & 7.03 & 5.52 & 6.27 & 6.42 & 5.14 & 5.78 & 8.02 & 7.78 & 7.90 \\
\hline N2: $50 \mathrm{~kg} \mathrm{~N} / \mathrm{fed}$. & 10.88 & 9.59 & 10.23 & 9.54 & 8.39 & 8.96 & 7.44 & 6.22 & 6.83 & 8.99 & 8.67 & 8.83 \\
\hline N3: $75 \mathrm{~kg} \mathrm{~N} / \mathrm{fed}$ & 11.58 & 10.12 & 10.85 & 10.16 & 9.02 & 9.58 & 7.78 & 6.63 & 7.20 & 9.21 & 8.85 & 9.03 \\
\hline L.S.D. $5 \%$ & 2.60 & 1.99 & 2.15 & 1.81 & 2.20 & 2.10 & 0.98 & 0.85 & 0.88 & 0.75 & 0.77 & 0.85 \\
\hline L.S.D. $1 \%$ & 3.05 & 2.65 & 2.80 & 2.50 & 2.70 & 2.61 & 1.00 & 1.05 & 0.98 & 0.90 & 0.86 & 0.92 \\
\hline \multicolumn{13}{|c|}{ Interactions } \\
\hline $\mathbf{V} \times P$ & N.S. & N.S. & N.S. & N.S. & N.S. & N.S. & N.S. & N.S. & N.S. & N.S. & N.S. & N.S. \\
\hline $\mathbf{V} \times \mathbf{N}$ & N.S. & N.S. & N.S. & N.S. & N.S. & N.S. & * & N.S. & * & N.S. & N.S. & N.S. \\
\hline $\mathbf{N} \times \mathbf{P}$ & N.S. & N.S. & N.S. & N.S. & N.S. & N.S. & N.S. & N.S. & N.S. & N.S. & N.S. & N.S. \\
\hline$V \times P \times N$ & N.S. & N.S. & N.S. & N.S. & N.S. & N.S. & N.S. & N.S. & N.S. & N.S. & N.S. & N.S. \\
\hline
\end{tabular}


Table (8): Mean values of seed yield and its related characters for two flax varieties as affected by potassin rates, nitrogen fertilizer levels and their interaction in 2003/2004 and 2004/2005 seasons in addition to the combined analysis.

\begin{tabular}{|c|c|c|c|c|c|c|c|c|c|c|c|c|}
\hline Characters & \multicolumn{3}{|c|}{ Seed yield/plant $(\mathbf{g})$} & \multicolumn{3}{|c|}{ Seed yield/fed. (kg) } & \multicolumn{3}{|c|}{ Seed oil percentage (\%) } & \multicolumn{3}{|c|}{ Oil yield/fed. (kg) } \\
\hline Treatments & 1 st & $2^{\text {nd }}$ & Comb. & 1 st & $2^{\text {nd }}$ & Comb. & $1^{\text {st }}$ & $2^{\text {nd }}$ & Comb. & 1 st & $2^{\text {nd }}$ & Comb. \\
\hline \multicolumn{13}{|c|}{ Varieties: } \\
\hline$V_{1}$ : Sakha 1 & 0.535 & 0.430 & 0.483 & 379.61 & 331.21 & 355.41 & 37.41 & 36.67 & 37.04 & 142.87 & 122.14 & 132.50 \\
\hline$V_{2}$ : Sakha 2 & 0.719 & 0.589 & 0.654 & 476.74 & 417.63 & 447.18 & 38.57 & 37.71 & 38.14 & 184.86 & 158.22 & 171.54 \\
\hline F. test & ** & ** & ** & * & * & ** & * & * & ** & * & * & ** \\
\hline \multicolumn{13}{|c|}{ Potassin rates } \\
\hline P1: 1 liter/fed. & 0.575 & 0.463 & 0.519 & 404.98 & 358.24 & 381.61 & 37.16 & 36.33 & 36.74 & 151.52 & 130.99 & 141.26 \\
\hline P2: 1.5 liter/fed. & 0.680 & 0.555 & 0.618 & 451.36 & 390.60 & 420.98 & 38.82 & 38.05 & 38.44 & 176.21 & 149.36 & 162.79 \\
\hline L.S.D. 5\% & 0.088 & 0.070 & 0.077 & 34.6 & 27.8 & 35.7 & 1.04 & 1.57 & 1.32 & 19.20 & 16.5 & 15.20 \\
\hline L.S.D. 1\% & 0.102 & 0.090 & 0.091 & 49.0 & N.S. & 38.5 & 1.60 & 1.71 & 1.92 & 23.8 & 18.01 & 18.9 \\
\hline \multicolumn{13}{|c|}{ Nitrogen fertilizer levels } \\
\hline N1: 25 kg N/fed. & 0.469 & 0.372 & 0.420 & 339.84 & 285.38 & 312.61 & 36.36 & 35.96 & 36.16 & 123.85 & 103.09 & 113.47 \\
\hline N2: 50 kg N/fed. & 0.686 & 0.547 & 0.617 & 471.48 & 410.52 & 440.99 & 38.65 & 37.66 & 38.15 & 182.85 & 154.90 & 168.87 \\
\hline N3: $75 \mathrm{~kg} \mathrm{~N} / \mathrm{fed}$ & 0.728 & 0.609 & 0.668 & 473.20 & 427.38 & 450.29 & 38.97 & 37.95 & 38.46 & 184.89 & 162.54 & 173.72 \\
\hline L.S.D. 5\% & 0.198 & 0.156 & 0.180 & 119.5 & 110.31 & 118.8 & 1.95 & 1.25 & 1.75 & 41.8 & 43.5 & 49.2 \\
\hline L.S.D. 1\% & 0.210 & 0.171 & 0.191 & 130.6 & 121.2 & 125.7 & 2.11 & 1.69 & 1.89 & 55.5 & 49.6 & 53.7 \\
\hline \multicolumn{13}{|c|}{ Interactions } \\
\hline $\mathbf{V} \times \mathbf{P}$ & ** & ** & ** & N.S. & N.S. & N.S. & N.S. & N.S. & N.S. & N.S. & N.S. & N.S. \\
\hline $\mathbf{V} \times \mathbf{N}$ & N.S. & N.S. & N.S. & N.S. & N.S. & N.S. & N.S. & N.S. & N.S. & N.S. & N.S. & N.S. \\
\hline $\mathbf{N} \times \mathbf{P}$ & N.S. & N.S. & N.S. & N.S. & N.S. & N.S. & N.S. & N.S. & N.S. & N.S. & N.S. & N.S. \\
\hline $\mathbf{V} \times \mathbf{P} \times \mathbf{N}$ & N.S. & N.S. & N.S. & N.S. & N.S. & N.S. & N.S. & N.S. & N.S. & N.S. & N.S. & N.S. \\
\hline
\end{tabular}


Table (11): Simple correlation coefficients among some studied characters for flax varieties as affected by potassin rates and nitrogen fertilizer levels (combined analysis of 2003/2004 and 2004/2005 seasons).

\begin{tabular}{|c|c|c|c|c|c|c|c|c|c|c|c|c|}
\hline Variables & 1 & 2 & 3 & 4 & 5 & 6 & 7 & 8 & 9 & 10 & 11 & 12 \\
\hline 1- Straw yield/fed. & $-\cdots-$ & $0.921^{* *}$ & $0.967^{* *}$ & $0.954^{\star \star}$ & $0.978^{\star *}$ & $0.916^{\star \star}$ & $0.981^{\star *}$ & -0.063 & 0.344 & 0.363 & 0.163 & 0.425 \\
\hline 2- Straw yield/plant & & --- & $0.877^{\star *}$ & $0.856^{\star \star}$ & $0.930^{* *}$ & $0.984^{\star \star}$ & $0.921^{\star \star}$ & 0.189 & 0.155 & 0.151 & -0.041 & 0.256 \\
\hline 3- Total length/plant & & & 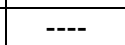 & $0.972^{\star \star}$ & $0.958^{\star *}$ & $0.878^{\star \star}$ & $0.981^{\star \star}$ & -0.209 & 0.484 & -0.390 & 0.252 & 0.490 \\
\hline 4- Technical length/plant & & & & ---- & $0.964^{* *}$ & $0.878^{\star *}$ & $0.982^{\star \star}$ & -0.290 & 0.023 & 0.448 & 0.223 & 0.457 \\
\hline 5- Fiber yield/fed. & & & & & ---- & $0.956^{\star *}$ & $0.976^{\star \star}$ & -0.118 & 0.417 & 0.440 & 0.234 & 0.506 \\
\hline 6- Fiber yield/plant & & & & & & ---- & $0.923^{\star \star}$ & 0.096 & 0.249 & 0.274 & 0.044 & 0.368 \\
\hline 7- Fiber length & & & & & & & $-\overline{---}$ & -0.158 & 0.359 & 0.359 & -0.098 & $-0.824^{\star \star}$ \\
\hline 8- Fiber fineness & & & & & & & & ---- & $-0.624^{*}$ & $-0.602^{*}$ & -0.550 & -0.457 \\
\hline 9- Seed yield/fed. & & & & & & & & & ---- & $0.982^{\star *}$ & $0.930^{\star *}$ & $0.919^{* *}$ \\
\hline 10- Seed yield/plant & & & & & & & & & & ---- & $0.960^{\star *}$ & $0.962^{\star \star}$ \\
\hline 11- No. of capsules/plant & & & & & & & & & & & ---- & $0.923^{\star \star}$ \\
\hline 12- 1000 seed weight & & & & & & & & & & & & ---- \\
\hline
\end{tabular}

